\title{
PEMBUATAN GAME EDUKATIF MENGGUNAKAN APP INVENTOR DENGAN TEMA MATA PELAJARAN KIMIA
}

\author{
Rizky Parlika ${ }^{1}$, Olivia Anggun Permatasari ${ }^{2}$, Rifardi Taufiq Yufananda ${ }^{3}$, Dimas \\ Rizward Hikmah Utomo ${ }^{4}$, Mochammad Zayyan Ramadhan ${ }^{5}$ dan Isfan Rachmad \\ Avianto 6
}

\author{
, Universitas Pembangunan Nasional “Veteran” Jawa Timur ${ }^{1,2,3,4,5,6}$ \\ rizkyparlika.if@gmail.com ${ }^{1}$, oliviaanggun.if@gmail.com ${ }^{2}$, \\ rifarditaufiqyufananda.if@gmail.com ${ }^{3}$, drizward.if@gmail.com ${ }^{4}$, \\ zayyanramadhan.if@gmail.com ${ }^{5}$, isfanrachmadavianto.if@gmail.com ${ }^{6}$.
}

\begin{abstract}
The problem in this research is to make a suitable learning media applied to high school students as an independent media and interkative, So that the application of learning model used by the teacher is not boring tend to be fun and can improve learning outcomes. The objectives of the researcher to accomplish is to develop and produce android application products in the form of educational media learning games about Chemistry, and know the feasibility and effectiveness of educational game applications as learning media for student study supplement with Chemical material. This research method using Research and Development method with design / design is pre-experimental design with one-group pretest-posttest design. The results that have been obtained is to produce application products android educational game Chemistry. It can be concluded educational game media application of Chemistry learning and effective as learning media for student study supplement.
\end{abstract}

Keywords-App Inventor, Chemistry, Android

\begin{abstract}
Abstrak: Permasalahan dalam penelitian ini adalah untuk membuat media pembelajaran yang cocok diterapkan kepada siswa SMA sebagai media yang mandiri dan interkatif, Sehingga penerapan model pembelajaran yang dipakai oleh guru tidak membosankan cenderung menyenangkan dan bisa meningkatkan hasil belajar. Adapun tujuan yang hendak peneliti capai yaitu dengan dapat mengembangkan dan menghasilkan produk aplikasi android berupa game edukasi media pembelajaran tentang Kimia, dan mengetahui kelayakan dan keefektifan aplikasi game edukasi sebagai media pembelajaran untuk suplemen belajar siswa dengan materi Kimia. Metode penelitian ini menggunakan metode Research and Development dengan desain/rancangan adalah pre-experimental design dengan bentuk one-group pretest-posttest design. Hasil penelitian yang telah didapatkan adalah menghasilkan produk aplikasi android game edukasi Kimia. Hal ini dapat disimpulkan aplikasi game edukasi media pembelajaran Kimia dan efektif sebagai media pembelajaran untuk suplemen belajar siswa.
\end{abstract}

Kata Kunci-App Inventor, Kimia, Android

\section{Pendahuluan}

Kegiatan pembelajaran merupakan kegiatan yang paling pokok dalam keseluruhan proses pendidikan. Belajar merupakan perubahan perilaku. Untuk mengukur apakah seseorang telah belajar, maka diperlukan perbandingan antara perilaku sebelum dan setelah mengalami 
menghasilkan produk aplikasi android berupa game edukasi media pembelajaran tentang Kimia, dan mengetahui kelayakan dan keefektifan aplikasi game edukasi sebagai media pembelajaran untuk suplemen belajar siswa dengan materi Kimia. Metode penelitian ini menggunakan metode Research and Development dengan desain/rancangan adalah pre-experimental design dengan bentuk one-group pretest-posttest design. Hasil penelitian yang telah didapatkan adalah menghasilkan produk aplikasi android game edukasi Kimia. Hal ini dapat disimpulkan aplikasi game edukasi media pembelajaran Kimia dan efektif sebagai media pembelajaran untuk suplemen belajar siswa.

\section{Kata Kunci-App Inventor, Kimia, Android}

\section{Pendahuluan}

Kegiatan pembelajaran merupakan kegiatan yang paling pokok dalam keseluruhan proses pendidikan. Belajar merupakan perubahan perilaku. Untuk mengukur apakah seseorang telah belajar, maka diperlukan perbandingan antara perilaku sebelum dan setelah mengalami kegiatan belajar, perubahan perilaku itu terjadi karena didahului oleh proses pengalaman dan bersifat relatif permanen. Siswa sering merasa jenuh saat proses belajar mengajar karena materi pembelajaran yang berkaitan dengan penghitungan cenderung sulit dipahami apalagi guru hanya menggunakan metode ceramah. Metode ceramah yang disampaikan oleh guru akan semakin mengurangi minat siswa dalam belajar apabila komunikasi terasa membosankan. Para siswa sering tidak aktif dalam pembelajaran di kelas dan hanya berperan sebagai pendengar.

Pada proses pembelajaran, media pengajaran merupakan wadah dan penyalur pesan dari sumber pesan, dalam hal ini guru, kepada penerima pesan, dalam hal ini siswa. Dalam batasan yang lebih luas, Yusufhadi Miarso memberikan batasan media pengajaran sebagai segala sesuatu yang dapat digunakan untuk merangsang pikiran, perasaan, perhatian, dan kemauan siswa sehingga mendorong terjadinya proses belajar pada diri siswa. [8]

Semakin pesat penggunaan Information technologi (IT) saat ini sejak ada tuntutan efisiensi waktu dalam belajar agar pengguna dapat memanfaatkan waktu sebaik mungkin. Dalam pelatihan yang diselenggarakan oleh lembaga pendidikan digunakan alat bantu papan tulis, buku-buku, diktat, Over Head Projector $(O H P)$, slide, dan lain-lain yang kurang menarik dan efisien dalam kegiatan belajar karena alat bantu yang digunakan terdapat kendala, misalnya malas menulis, malas mencatat .

Dengan pesatnya perkembangan teknologi jaringan seluler, perangkat seluler menjadi semakin kuat. Pada tahun 2017, pengiriman ponsel pintar berjumlah sekitar 1,47 miliar unit1. Pada kuartal kedua 2017, Android menyumbang sekitar 87,7\% pangsa pasar OS seluler2. Perangkat ponsel Android memainkan peran yang sangat penting dalam kehidupan dan pekerjaan orang-orang, dan pentingnya forensik Android semakin meningkat. [1]

Dalam bidang Teknologi gadget mengalami peningkatan yang sangat positif. Mulai dari sistem operasi (Operating System) disingkat OS symbian sampai yang dikenal masyarakat yaitu $O S$ android. Berbagai aplikasi yang dapat diterapkan sebagai teman belajar 
sangat sedikit peminatnya misal saja game. Nilai positif yang sebenarnya ada terkandung dalam game tersebut seringkali tidak disadari oleh pengguna (siswa). Game hanya sebatas alat untuk mencari hiburan sebagai solusi dari kepenatan, kegalauan setelah melakukan aktifitas. Hal ini sudah menjadi paradigma pecandu game sebagian besar siswa SMA, SMK sederajat. Perlu ada solusi yang tepat selain sebagai hiburan, game juga bisa dijadikan alat komunikasi dan teman belajar siswa.

Berdasarkan latar belakang yang diuraikan maka peneliti menyusun dengan judul "Pembuatan Game Edukatif menggunakan App-Inventor menunjang pembelajaran Mata Pelajaran Kimia".

\section{TINJAUAN PUSTAKA}

\subsection{Serious Game}

Serious game adalah suatu konsep game dengan tujuan untuk kepentingan trainning, advertising, simulasi, edukasi. Intinya adalah untuk kepentingan yang sifatnya nonentertainment. Implementasinya, serious game ini bisa diterapkan untuk berbagai tingkatan usia serta dengan berbagai genre dan teknologi game. [3]

Menurut Julian Alvarez (2007), Serious Game adalah, "aplikasi komputer, yang bertujuan untuk menggabungkan aspek-aspek baik yang serius, namun tidak terbatas pada, pengajaran, pembelajaran, komunikasi, atau informasi lebih lanjut dengan hiburan dari permainan musim semi. sebuah asosiasi bermaksud untuk berangkat dari hiburan belaka. " Definisi yang dikutip terkait dengan konsultasi beberapa contoh permainan serius, telah memungkinkan kita untuk menyoroti karakteristik berikut dari jenis media:

- Sebuah prioritas pengajaran objek: permainan yang serius adalah proses pembelajaran;

- Sarana hiburan secara paralel: permainan yang serius adalah permainan

- Teknologi informasi dan komunikasi: permainan yang serius adalah aplikasi teknologi video game;

- Ini menargetkan beberapa tujuan pembelajaran: untuk mengajar, melatih, mendidik, menyembuhkan;

- Ini berlaku di hampir setiap bidang: pendidikan, pelatihan kejuruan, kesehatan, pertahanan, politik, periklanan, bisnis;

- Ini ditujukan untuk semua kelompok umur: anak-anak, [7]

\subsection{Android}

Ponsel pintar telah mengubah kehidupan orang secara dramatis dalam dekade terakhir berkat fungsi dan mobilitas yang disediakan. Android memimpin pasar sistem operasi seluler dengan digunakan pada lebih dari 2 miliar perangkat aktif bulanan. Menurut laporan terbaru oleh IDC1, Android mendominasi pasar smartphone global dengan digunakan pada $85 \%$ ponsel pintar di seluruh dunia. Diperkirakan pangsa pasar global Android diperkirakan akan meningkat menjadi $90 \%$ pada tahun 2017. Sebagai hasil dari popularitas ini, pasar aplikasi resmi, Play Store, digunakan untuk menginstal 82 miliar aplikasi pada tahun 2016. Dilaporkan bahwa Play Store adalah tumbuh tiga kali lipat dari Apple App Store yang merupakan pasar aplikasi resmi iOS dan pasar aplikasi mobile resmi terbesar setelah Play Store. Sebagai hasil dari popularitas ini, Play Store menarik perhatian pengembang perangkat Android. [4] 
Pemilihan telepon seluler platform berbasis Android untuk salah satu pengembangan aplikasi selain bersifat open source dan lebih mudah dalam pengoperasiannya, sifat dari telepon seluler yang fleksibel menjadi juga salah satu alasannya. [9]

\subsection{Game Edukasi}

Edukasi adalah proses yang dilakukan oleh seseoarang untuk menemukan jati dirinya, yang dilakukan dengan mengamati dan belajar yang kemudian melahirkan tindakan dan prilaku. Edukasi sebenarnya tidak jauh berbeda dari belajar yang dikembangkan oleh aliran behaviorisme dalam psikologi. Hanya istilah ini sering dimaknai dan diinterpretasikan berbeda dari learning yang bermakna belajar. Dan istilah ini seringkali digunakan dalam pendekatan pendidikan yang tentu maknanya lebih dari sekedar belajar. Secara umum anak usia dini merupakan anak yang berada pada usia 0-6 tahun. [10]

Game edukasi berbasis simulasi didesain untuk mensimulasikan permasalahan yang ada sehingga diperoleh esensi atau ilmu yang dapat digunakan untuk menyelesaikan permasalahan tersebut. Game simulasi dengan tujuan edukasi ini dapat digunakan sebagai salah satu media edukasi yang memiliki pola pembelajaran learning by doing. [2]

Game edukasi sangat menarik untuk dikembangkan. Ada beberapa kelebihan darigame edukasi dibandingkan dengan metode edukasi konvensional. Salah satu kelebihan utama game edukasi adalah pada visualisasi dari permasalahan nyata. Massachussets Insitute of Technology (MIT) berhasil membuktikan bahwa game sangat berguna untuk meningkatkan logika dan pemahaman pemain terhadap suatumasalah melalui proyek game yang dinamai Scratch. Berdasarkan hasil penelitian sebelumnya, tidak diragukan lagi bahwa game edukasi dapat menunjang proses pendidikan.

\subsection{App Inventor}

App Inventor for Android adalah aplikasi web open-source yang awalnya disediakan oleh Google, dan sekarang dikelola oleh Massachusetts Institute of Technology (MIT). Hal ini memungkinkan pendatang baru ke pemrograman komputer untuk membuat aplikasi perangkat lunak untuk sistem operasi Android (OS). Ini menggunakan antarmuka grafis, sangat mirip dengan Scratch dan antarmuka pengguna TNG StarLogo, yang memungkinkan pengguna untuk menyeret dan menjatuhkan objek visual untuk membuat aplikasi yang dapat berjalan di perangkat Android. Dalam menciptakan App Inventor, Google tertarik pada penelitian sebelumnya yang signifikan dalam komputasi pendidikan, serta pekerjaan yang dilakukan dalam Google pada lingkungan.

Dalam memblok bahasa, program dibangun dengan menghubungkan fragmen visual (blok) yang berbentuk seperti potongan-potongan jigsaw puz-zle. MIT App Inventor (AI) [1] mendemokrasikan pemrograman untuk aplikasi seluler Android melalui bahasa blok yang mudah digunakan. Beberapa fitur AI mengurangi rasa frustrasi sintaksis dan kognitif yang dialami oleh pemula ketika belajar pemrograman tekstual: blok dipilih dari menu-menu dari blok terkait; bentuk colokan dan soket menyarankan bagaimana blok-blok itu saling menyatu; dan label pada soket mendokumentasikan tujuan mereka. [5]

App Inventor membuat programmer menjadi lebih mudah dalam pembuatan dan pengembangan game walaupun terjadi lack pada proses programming. Dengan menggunakan component design dapat dibuat sebuah aplikasi pada android dengan mudah karena programmer 
dapat melihat secara nyata pembuatan menu atau tombol-tombol. Dengan menggunakan block editor, pengguna dapat melihat bagaimana kondisi dibalik aplikasi yang dibuat. Sehingga pengguna dapat mengubah dengan mudah sesuai keinginan tanpa menggunakan kode.

\subsection{Kimia}

Kimia merupakan mata pelajaran adaptif di Sekolah Menengah Kejuruan (SMK), sehingga cenderung diremehkan atau dianggap tidak penting oleh siswa. Pelajaran adaptif bukanlah pelajaran utama, tetapi hanya merupakan pelajaran yang menunjang pelajaranpelajaran produktif. Hal ini berakibat masih rendahnya prestasi belajar kimia siswa kelas XI, untuk materi ikatan kimia dalam empat tahun terakhir. Rata-rata siswa yang mencapai nilai ulangan harian di atas kriteria ketuntasan minimal (KKM) dalam empat tahun terakhir hanya $60 \%$ dari jumlah siswa. [6]

Kimia kadang-kadang disebut sebagai ilmu pengetahuan pusat karena menjembatani ilmu-

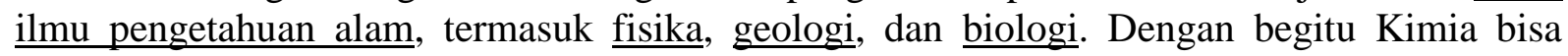
dikatakan cabang ilmu yang penting.

\section{Metodologi Penelitian}

Pada penelitian ini menggunakan metode penelitian dan pengembangan (Research and Development). Metode penelitian dan pengembangan adalah metode yang digunakan untuk menghasilkan suatu produk tertentu dan menguji keefektifan produk tersebut. Untuk menghasilkan suatu produk tertentu penelitian dilakukan dengan melakukan analisis kebutuhan dan kegunaan produk tersebut bagi lingkungan sekitar.

Penelitian ini bertujuan untuk mengembangkan media pembelajaran berupa aplikasi pembelajaran berbasis game edukasi yang berisi soal-soal kimia tingkat SMA dan sederajat. Game ini berisi soal-soal latihan yang mengandung bab-bab dari kelas X sampai kelas XII. Soal-soal berupa soal pilihan ganda dengan model soal konsep-konsep, penerapan rumus secara langsung atau penerapan dalam kehidupan sehari-hari. Game edukasi ini sangat bermanfaat bagi siswa yang akan mempersiapkan ujian-ujian atau tes atau bisa digunakan sebagai media pembelajaran mandiri untuk melatih otak dan memperbanyak latihan.

Game ini dibuat dengan menggunakan App Inventor 2. Dengan menggunakan tool ini, karena tidak perlu terlalu paham tentang koding. Pada tool ini menyediakan fitur component designer dan editor block. Component designer untuk mengatur interface dari game yang akan dibuat. Pengaturan interface yang bisa dilakukan misalnya pengaturan background, pengaturan tombol, penyisipan backsound, dan pengaturan timer.Editor Block di sini digunakan untuk melakukan pembuatan fungsi dari game ini. Misalnya pengaturan pada timer dengan waktu berapa menit, peletakan backsound di bagian tertentu, perubahan perpindahan screen, pembuatan variabel, dan pengaturan lainnya. 


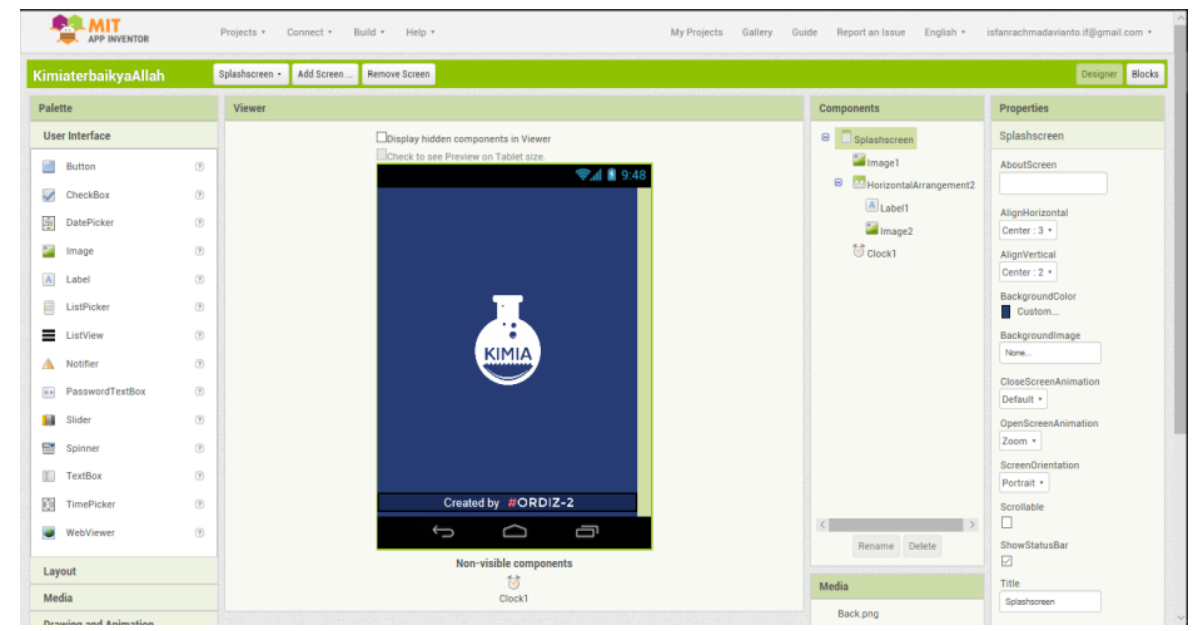

\section{Gambar 3.1 Component Designer}

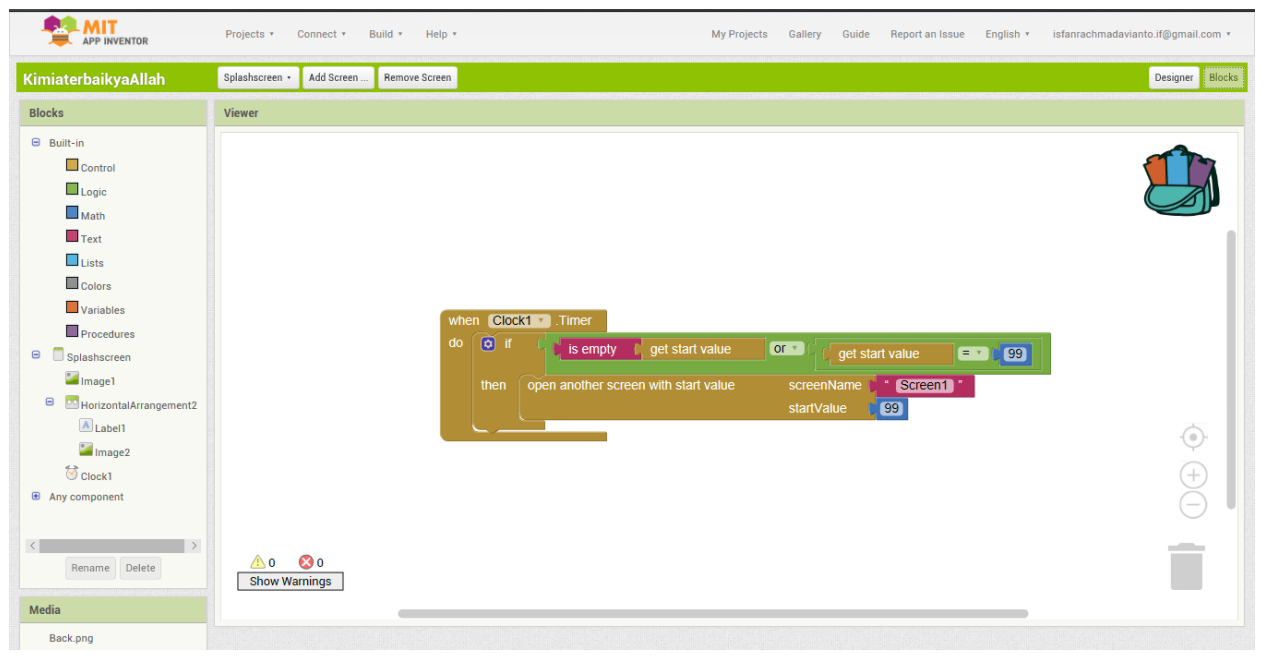

Gambar 3.2 Block editor

\section{HaSil dan Pembahasan}

Hasil dari penelitian ini adalah sebuah aplikasi game media pembelajaran kimia. Ada beberapa screen yang ada di aplikasi ini adalah splash screen, login screen, start screen, selection class, play screen, score screen, kunci jawaban screen, exit screen

\section{a. Splash screen.}

Screen yang pertama kali muncul ketika aplikasi dibuka. Kemudian tunggu 3 detik untuk menuju screen selanjutnya. 


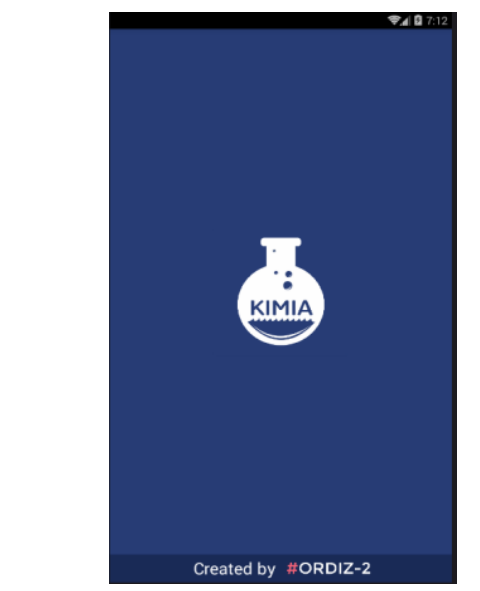

\section{Gambar 4.1 Splash Screen}

\section{b. Login Screen}

Screen sebagai login user sebelum memainkan game. Terdapat 3 cara login yaitu dengan : e-mail dan Facebook.

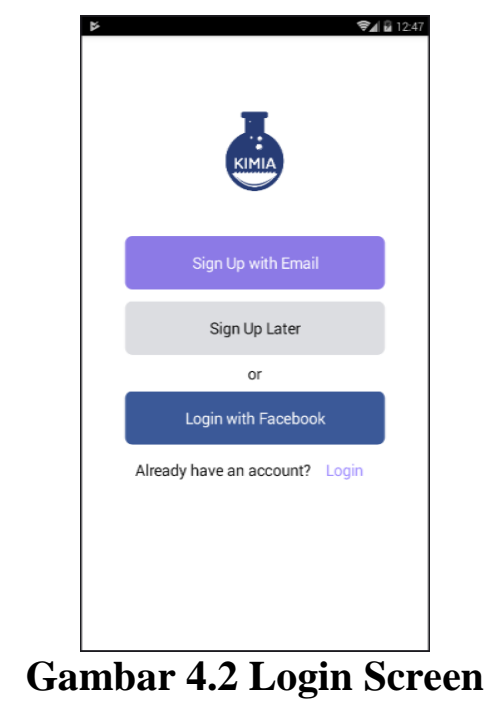

\section{c. Main Screen}

Screen yang memuat kelas dan menu highscore. User akan diberi pilihan kelas berapa yang ingin dimainkan. Dan menu HighScore untuk menampilkan Record permainan sebelumnya. 


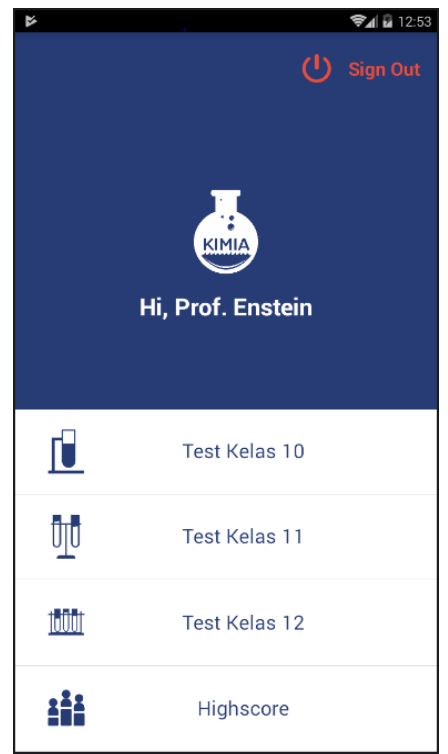

\section{Gambar 4.3 Main Screen}

\section{d. Selection Class}

Screen yang menyediakan kategori kelas pada user.Tinggal user memilih kelas mana yang ingin dimainkan. Disisi lain terdapat silabus di tiap-tiap kelas.

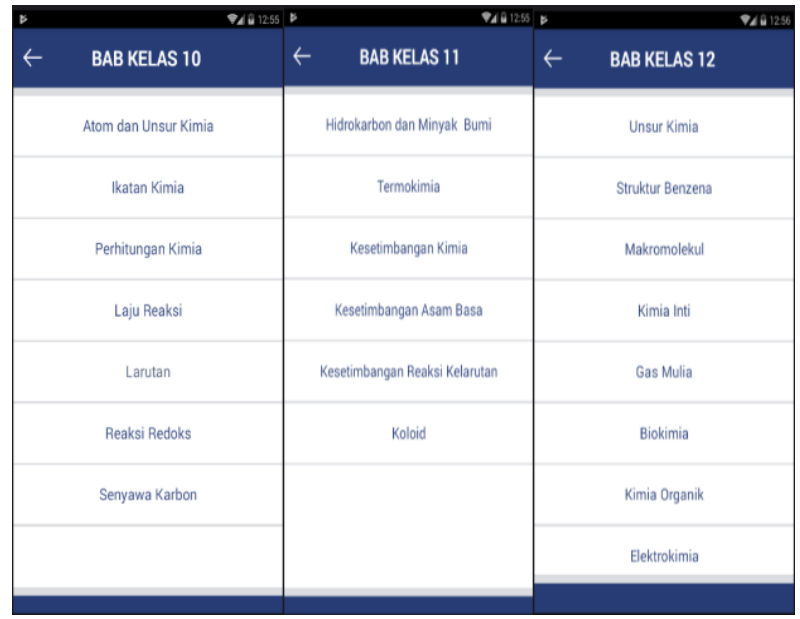

Gambar 4.4 Materi dalam tiap kelas

\section{e. Play Screen}

Screen ini memuat soal-soal dari masing-masing materi dalam pemilihan kelas. Dan dalam setiap soal diberi waktu 2 menit untuk menjawab. Lebih dari waktu tersebut maka jawaban dianggap salah. 


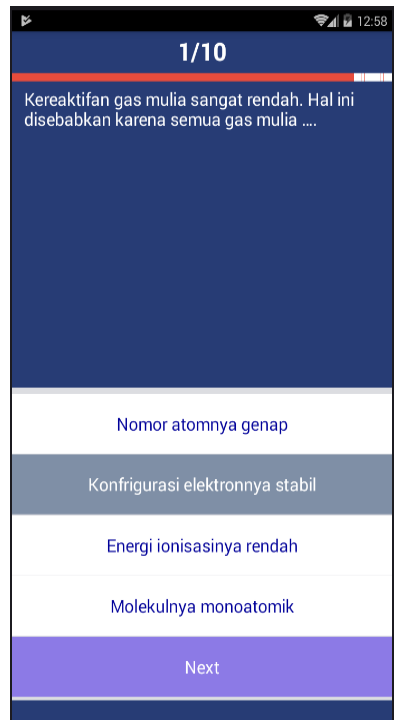

Gambar 4.5 Play Screen

\section{f. Score Screen}

Papan score ini akan menunjukkan score hasil dari nilai pemain. Nilai ini adalah benar dikalikan dengan sepuluh. Sehingga untuk nilai maksimal yaitu 10 soal dikalikan 10 menjadi 100. Berikut tampilan papan score.

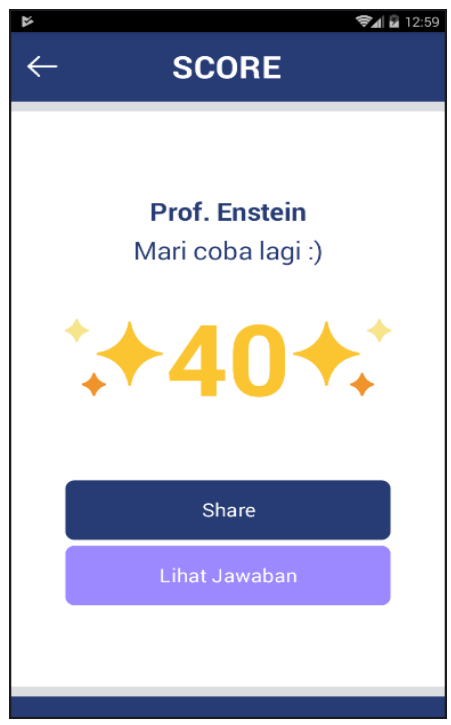

Gambar 4.6 Score Screen

g. See Answer Screen 
e-NARODROID

Volume IV, Juli 2018

ISSN 2407-7712

Halaman 1-12

Screen ini berfungsi untuk user ingin mengetahui kunci jawaban dari soal-soal yang telah dikerjakan. Screen nya akan ditampilkan setelah tampilan score.

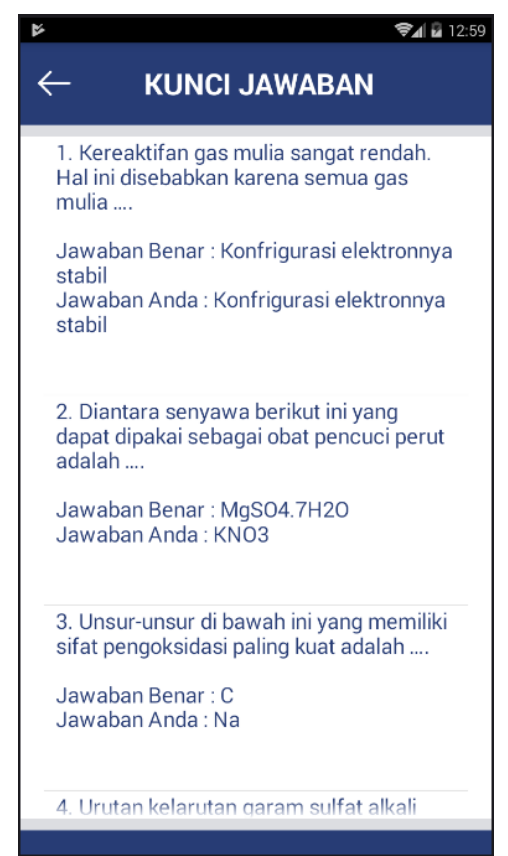

Gambar 4.7 See Answer Screen

\section{h. Highscore Screen}

Screen ini merupakan screen yang menampilkan hasil score teratas dari seluruh user dari nama, hasil score yang didapat, dan pada bab apa yang dimainkan.

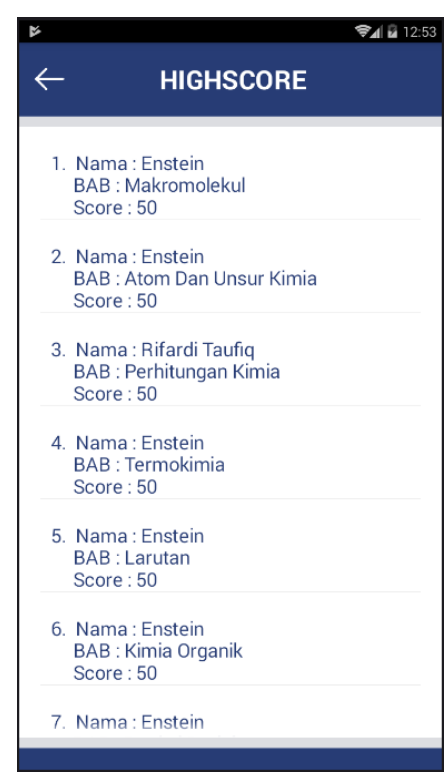

Gambar 4.8 Highscore Screen

\section{KESIMPULAN DAN SARAN}


Jadi, untuk membuat aplikasi game berbasis android, dapat menggunakan bantuan aplikasi atau software gratis seperti App Inventor yang hanya melakukan drag-and-drop tanpa harus mengcoding. Aplikasi game edukasi dapat membantu seseorang, dalam kasus ini yaitu siswa SMA untuk dapat belajar dan mengasah kemampuan mereka dalam menyelesaikan soalsoal Kimia dimanapun dan kapanpun, hanya dengan memainkan game edukasi di smartphone atau tablet mereka.

Penelitian yang dilakukan oleh Hendro Welas Setiawan : 2015 menunjukkan bahwa game edukasi pada smartphone sangat berpeluang menciptakan inovasi dalam peningkatan prestasi pada Siswa. Hal ini dapat disimpulkan aplikasi game edukasi media pembelajaran Kimia layak dan efektif sebagai media pembelajaran untuk suplemen belajar siswa

\section{DAFTAR PUSTAKA}

[1] Peijun Feng*, Qingbao Li, Ping Zhang, Zhifeng Chen (2018), "Logical Acquisition Method Based on Data Migration for Android Mobile Devices" State Key Laboratory of Mathematical Engineering and Advanced Computing, Zhengzhou, Henan, 450001, China

[2] Anik Vega Vitianingsih (2016), Game Edukasi Sebagai Media Pembelajaran Pendidikan Anak Usia Dini. Jurnal INFORM Vol. 1, No. 1, Hal. 1-2. (Sudah)

[3] Jina Kang and friends (2017), "Using gameplay data to examine learning behavior patterns in a serious game". In Computer in human behavior. Austin, TX, USA. (Sudah)

[4] Abdullah Talha Kabakus and friends (2016), "An in-depth analysis of Android malware using hybrid techniques." In Duzce University, Faculty of Engineering, Department of Computer Engineering, 81620, Duzce, Turkey. (Sudah)

[5] Kharisma Cadha and friends (2014), "Improving App Inventor usability via conversion between blocks and text" in MIT Lincoln Lab, Lexington 02421, USA. (Sudah)

[6] Tri Murtiningrum, Ashadi , Sri Mulyani (2013), "PEMBELAJARAN KIMIA DENGAN PROBLEM SOLVING MENGGUNAKAN MEDIA E-LEARNING DAN KOMIK DITINJAU DARI KEMAMPUAN BERPIKIR ABSTRAK DAN KREATIVITAS SISWA" Program Studi Pendidikan Sains, Program Pascasarjana, Universitas Sebelas Maret Surakarta, 57126, Indonesia.

[7] Houda Mouaheb , Ahmed Fahli , Mohammed Moussetad Said Eljamali (2012), "The serious game: what educational benefits?" a LIRADE-TIE ORDIPU, Faculté des sciences Ben'Msik, Casablanca 20700, Maroc b LMI, Faculté des sciences Ben'Msik, Casablanca 20700, Maroc c LIRADE-TIE ORDIPU, Centre pédagogique régional,Casablanca 20330,Maroc

[8] Nunu Mahnun (2012), “ MEDIA PEMBELAJARAN (Kajian terhadap Langkah-langkah Pemilihan Media dan Implementasinya dalam Pembelajaran).” Dosen Fakultas Tarbiyah dan Keguruan UIN Suska Riau 
e-NARODROID

Volume IV, Juli 2018

ISSN 2407-7712

Halaman 1-12

[9] Sulihati Andriyani (2016), "APLIKASI AKADEMIK ONLINE BERBASIS MOBILE ANDROID PADA UNIVERSITAS TAMA JAGAKARSA" Jurnal Sains dan Teknologi Utama, Volume XI, Nomor 1, April 2016

[10] Dian Wahyu Putra (1), A. Prasita Nugroho (2), Erri Wahyu Puspitarini (3) (2016), “ GAME EDUKASI BERBASIS ANDROID SEBAGAI MEDIA PEMBELAJARAN UNTUK ANAK USIA DINI " Program Studi Teknik Informatika, Fakultas Teknologi Informasi Universitas Merdeka Pasuruan 